\title{
Correction to: Coupled beta diversity patterns among coral reef benthic taxa
}

\author{
Jamie M. McDevitt-Irwin ${ }^{1}$ (1) - Carrie Kappel ${ }^{2}$ - Alastair R. Harborne ${ }^{3} \cdot$ Peter J. Mumby $^{4}$ - Daniel R. Brumbaugh ${ }^{5,6}$. \\ Fiorenza Micheli ${ }^{1,7}$
}

Published online: 15 March 2021

(c) The Author(s) 2021

\section{Correction to: Oecologia (2021) 195:225-234 https://doi.org/10.1007/s00442-020-04826-2}

Authors would like to update the missing Electronic Supplementary Material in Springerlink.

The original article has been corrected.

Open Access This article is licensed under a Creative Commons Attribution 4.0 International License, which permits use, sharing, adaptation, distribution and reproduction in any medium or format, as long as you give appropriate credit to the original author(s) and the source, provide a link to the Creative Commons licence, and indicate if changes were made. The images or other third party material in this article are included in the article's Creative Commons licence, unless indicated otherwise in a credit line to the material. If material is not included in the article's Creative Commons licence and your intended use is not permitted by statutory regulation or exceeds the permitted use, you will

The original article can be found online at https://doi.org/10.1007/ s00442-020-04826-2.

Jamie M. McDevitt-Irwin

jmcirwin@stanford.edu

1 Stanford University, Hopkins Marine Station, 120 Ocean View Blvd, Pacific Grove, CA 93950, USA

2 National Center for Ecological Analysis and Synthesis, 735 State Street, Santa Barbara, CA 93101, USA

3 Institute of Environment and Department of Biological Sciences, Florida International University, 3000 NE 151 Street, North Miami, Florida 33181, USA

4 School of Biological Sciences, University of Queensland, Brisbane, St Lucia QLD 4072, Australia

5 Department of Environmental Studies, University of California, Santa Cruz, 115 McAllister Way, Santa Cruz, CA 95060-5795, USA

6 Elkhorn Slough National Estuarine Research Reserve, 1700 Elkhorn Road, Watsonville, CA 95076, USA

7 Stanford Center for Ocean Solutions, 120 Ocean View Blvd, Pacific Grove, CA 93950, USA need to obtain permission directly from the copyright holder. To view a copy of this licence, visit http://creativecommons.org/licenses/by/4.0/. 